\title{
Is the same pollinator species equally effective in different populations of the generalist herb Alstroemeria ligtu var. simsii?
}

\section{¿Es la misma especie de polinizador igualmente efectiva en diferentes poblaciones de la hierba generalista Alstroemeria ligtu var. simsii?}

\author{
Maureen Murúa ${ }^{1,2,3}$, María José Ramírez ${ }^{4} \&$ Alejandra González ${ }^{4 *}$
}

${ }^{1}$ Centro de Investigación en Recursos Naturales y Sustentabilidad (Cirenys), Universidad Bernardo O’Higgins, Avenida Viel 1497, 8370993, Santiago, Chile.

${ }^{2}$ Fundación Flores, Ministro Carvajal 30, 7500801 Providencia, Santiago, Chile.

${ }^{3}$ Actual adress: Centro GEMA: Genómica, Ecología y Medio Ambiente, Facultad de Ciencias, Universidad Mayor, Camino La Pirámide 5750, 8580745, Santiago, Chile.

${ }^{4}$ Departamento de Ciencias Ecológicas, Facultad de Ciencias, Universidad de Chile, Santiago, Casilla 653, Santiago, Chile.

*apgonzalez@uchile.cl

\begin{abstract}
RESUMEN
En esta investigación estimamos la efectividad de polinización en tres poblaciones de Alstroemeria ligtu. Los resultados muestran que Lasia es el género de polinizador más frecuente, cuya efectividad varía entre poblaciones. Proponemos que la efectividad de polinización puede responder a condiciones locales que varían en el rango de distribución de la planta y sus polinizadores.
\end{abstract}

In the last decades, many studies have tried to determine how different floral traits (e.g., color, shape, odor) or pollinator syndromes reflect plant adaptations to particular pollinator species (review Rosas-Guerrero et al. 2014, Murúa \& Espíndola 2015). Although pollination specialization exists, most of the flowering plant species are visited by a diverse number of pollinator species, which has shown that generalist pollination is a predominant plant-animal interaction in nature (Waser et al. 1996, Herrera 2005, Ollerton et al. 2006). In those cases, the relative importance of pollinators as selective agents is not necessarily obvious. Since, the action of selection can vary depending on the diversity (species number), abundance (visitation frequency), and effectiveness (pollen carry over by visit) of each pollinator (Aigner 2001, Ne'eman et al. 2010, Sahli \& Conner 2011). In this respect, Stebbins (1970) proposed "The Most Effective Pollinator Principle", which raises that flower phenotype would be molded by the most frequent and effective pollinator species. So, even if a plant species presents a diverse pollinator assemblage, only some of them would have a greater impact on the reproductive success of the plant (Kay \& Sargent 2009).

Alstroemeria ligtu L. var. simsii (Spreng.) Ehr. Bayer (Alstroemeriaceae) is a perennial and hermaphroditic self-incompatible herb, which is completely dependent on pollinators for reproduction (Arroyo \& Uslar 1993). Along its range of distribution, their populations show a high spatial variation in their pollination assemblages, being visited by approximately 24 different species of insects belonging to the Diptera, Hymenoptera and Lepidoptera orders (González et al. 2014). Despite this, recent investigations have shown that most of the $A$. ligtu populations are mainly visited by the same pollinator species (e.g., Lasia corvina Erichson (1840) and Centris nigerrima Spinola (1851)), which are consistent among years (González et al. 2014, 2015), suggesting that they may engage in a more specialist, rather than generalist, plant-pollinator interaction. However, there is still unknown how effective are these species in transferring pollen to A. ligtu. According to this, it is possible to ask whether the same floral visitor could be equally effective in the pollination service provided to these populations. In order to answer this question, here we characterize the pollinator assemblages and determine the pollination effectiveness of the main pollinator species in three $A$. ligtu populations.

The study was conducted during the flowering season of 2014 (November - December) in three populations of central Chile Cuesta Zapata, Río Clarillo and Termas del Flaco, where $A$. ligtu flowers dominated the area (Fig. 1A-B). All populations are characterized by a Mediterranean-type climate with strong rains during wintertime (Di Castri \& Hajek 1976). The population Cuesta Zapata (ZA; 33³9'19'" S; 70¹9'23" W) occurs in Coastal hills at 529 masl, where the site is dominated by Quillaja saponaria Molina and different herbs species such as Alstroemeria pulchra Sims, A. angustifolia Herb., Carduus pycnocephalus L., Sisymbrium officinale (L.) Scop., Loasa tricolor Ker Gawl., 
Clarkia tenella (Cav.) F.H. Lewis \& M.E. Lewis, Oxalis rosea Jacq., Eschscholzia californica Cham., Calceolaria sp., Schizanthus tricolor Grau \& Gronbach, and Papaver sp. (pers. obs.). Río Clarillo population (RC; 3346'80" S; $71^{\circ} 49^{\prime} 72^{\prime \prime} \mathrm{W}$ ) is located in the pre-Andean mountains at 1153 masl, where individuals of $A$. ligtu are inhabiting with a diverse assemblages of trees, scrubs and herbs species like Cryptocarya alba (Molina) Looser, Quillaja saponaria, Escallonia pulverulenta (Ruiz \& Pav.) Pers., A. angustifolia, Carduus pycnocephalus, Conium maculatum L., Leucheria sp., Madia chilensis (Nutt.) Reiche, Stellaria chilensis Pedersen, Geranium berteroanum Colla, Sisyrinchium sp., Stachys grandidentata Lindl., Leucocoryne ixioides (Hook.) Lindl., Pasithea caerulea (Ruiz \& Pav.) D. Don, Loasa tricolor, Clarkia tenella, and Schizanthus tricolor (pers. obs.). Whereas the third population occurs on road to Termas del Flaco (TF; 34 $60^{\prime} 87^{\prime \prime} \mathrm{S} ; 7^{\circ} 49^{\prime} 72^{\prime \prime} \mathrm{W}$ ) at 585 masl, where plants are mainly surrounding by herbs such as Hypericum perforatum L., Sisyrinchium sp., Anagallis arvensis L., Rubus ulmifolius Schott and Calceolaria sp. (pers. obs.).

In each population, we selected three random patches of plants separated by 3 meters. A total of 482 plants were studied $(\mathrm{ZA}=200, \mathrm{RC}=200, \mathrm{TF}=82)$. All individuals were tagged and monitored during 2 to 4 days per months. In order to characterize flower size one flower per plant were cut and photographed from a frontal view. Corolla area $\left(\mathrm{mm}^{2}\right)$ were measured from digitalized photos and analyzed using Image J Laucher program version 1.45 (available online: https://imagej.nih.gov/ij/). Pollinator visitation regimens were quantified through focal observations during 15 min per plant, in sunny days between 10:00 and 15:00 hours. Visitation rate was calculated as the number of visits per flower per hour (visits*flower ${ }^{-1 *}$ hour $^{-1}$ ). In addition, the handling time (i.e., the time speeded in a flower during a single visit) of each pollinator species was recorded. Only the most frequent pollinators were captured and stored in Eppendorf tubes with $1 \mathrm{ml}$ of ethanol. The insects were moved to laboratory for pollen load counting. All captured pollinators were photographed, and their body lengths were measured in ImageJ Laucher program. Pollen was removed from pollinator's body by shaking tubes in a vortex for 1 minute. From each tube, we took one aliquot of $0.3 \mathrm{ml}$ and we put in a Neubauer chamber for quantification. In this way, under microscope we identified and quantified the pollen grains of $A$. ligtu and the other plant species based on the description made by Arredondo-Núñez (2010). This procedure was carried out three times and pollinator pollen load (PL) was estimated as the average number of pollen grains transported. Since the number of pollen grains carried on the body has been related to the pollinator body length (Griffin et al. 2009) we standardized our data by dividing the pollen grains by pollinator's total body length $(\mathrm{mm})$.

To identify the main pollinator species of each population the five species with the highest visitation frequency were selected using the results of an ANOVA test. Once the main pollinator per population was identified, their pollinator effectiveness was estimated as VR*PL (Ne'eman et al. 2010). Finally, to determine statistical differences in visitation rate, pollinator effectiveness and handing time of main pollinator species a GLM with Gaussian distribution was performed. All variables were transformed to $\log (\mathrm{x}+1)$ previously to the analysis in R package (Core Team 2018).

Corolla size measurements for all A. ligtu populations are presented in Table 1 . The largest corolla areas were observed in plants inhabiting $\mathrm{RC}$, followed by ZA, and the smallest ones were quantified in TF. Respecting to pollinator visitation regimens, a total of 798 visits by 22 pollinator species were registered in approximately $60 \mathrm{~h}$ of observation per population (RC: $63.5 \mathrm{~h}, \mathrm{TF}: 69.5 \mathrm{~h}, \mathrm{ZA}$ : $66.8 \mathrm{~h}$; Appendix 1). Hymenoptera was the order with the highest number of species (12 species), followed by Diptera (8 species) and Lepidoptera ( 2 species). When only the most frequent pollinators were considered per population, the ANOVA test showed significant differences in the visitation rates of the five species with the highest visitation frequency in each A. ligtu populations (Table 2). The species of the dipteran genus Lasia were the most frequent pollinators in the three populations. Lasia corvina was the most frequent pollinator species in RC and TF, with the $62 \%$ and $85 \%$ of the total visits, respectively (Fig. 1C). While, Lasia aenea Philippi (1865) was the responsible of $50 \%$ of the visits in ZA population (Fig. 1D).

L. corvina showed a higher visiting rate in $\mathrm{RC}$ than in $\mathrm{TF}$, and L. aenea in ZA (Fig. 1E). L. corniva showed thirteen times higher effectiveness in RC than in TF, while that $L$. aenea in ZA was also higher than L. corvina in TF (Fig. $1 F)$. While, pollinator handling time species was mostly the same in each A. ligtu populations (Fig. 1G). Finally, GLM analysis showed significant differences in the visitation rate and pollinator effectiveness, but not in the handling time of main pollinator species among sites (Table 3 ).

Results of this study reveal that not only the visitation rate, but also the pollinator effectiveness can vary among A. ligtu populations, even if the same pollinator genus or species are the responsible of most of the visits in a population. Here, we found that Lasia corvina was the main pollinator in two of the three study populations ( $\mathrm{RC}$ and TF) and $L$. aenea was in the third one (ZA). Where, they showed different visitation frequency and pollinator effectiveness, which seems not to be related to pollinator handling time. Pollinator choices are based on different floral cues which together favored their performance and gain in the foraging process (Waser 1983). In RC population, L. corvina visited more frequently and effectively the flowers of $A$. ligtu than those in TF and ZA, but in the later $L$. aenea showed higher pollination effectiveness than L. corvina in TF. Pollination foraging behavior and consequently the success of the 
pollination process depend on several non-exclusive factors both at the individual and community scale. At the individual level, flower size is an important visual signal in pollinator attraction, where it is known that plants with larger corolla sizes could have a higher chance to be visited than smaller ones (Conner \& Rush 1996). In RC, flowers have larger corolla areas than those in TF and ZA (Table 1), which might increase the probability of pollen recollection. In the same way, plants in ZA showed a higher corolla area than plants in TF, which could explain the higher mean visitation rate of $L$. aenea. At the community scale, an important factor that can also compromise pollination effectiveness is the composition of co-flowering species within a plant community (Hegland \& Boeke 2006). Pollination sharing can lead to pollen competition by visitation loss or interspecific pollen transfer, where plant species can steal pollinators reducing visitation frequency and/or they could perform mixed visits increasing pollen exchange between
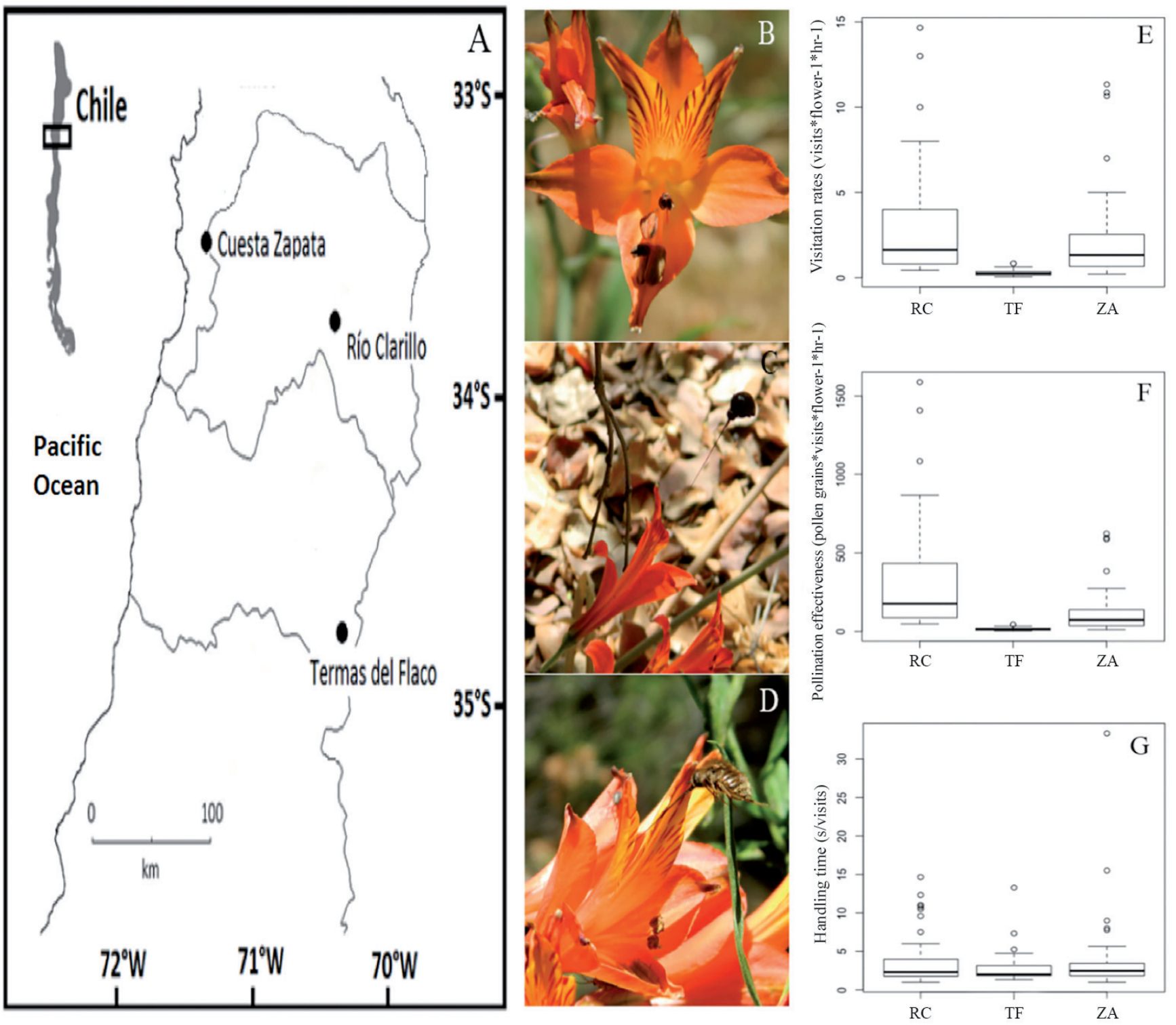

FIGURE 1. Geographical distribution of studied populations, Alstroemeria ligtu flower detail, pollinator species and differences in the visitation rate, pollination effectiveness and handling time of the main pollinator species of each $A$. ligtu study populations. A) Populations locations, B) A. ligtu flower, C) Lasia corvina, D) L. aenea, E) Visitation rate, F) Pollination effectiveness, and G) Handling time. / Distribución geográfica de las poblaciones estudiadas, detalle de la flor de Alstroemeria ligtu, especies de polinizadores y diferencias en las tasas de visita, efectividad de polinización y tiempo de manipulación del principal polinizador de cada población en estudio de $A$. ligtu. A) Ubicación de las poblaciones, B) Flor de A. ligtu, C) Lasia corvina, D) L. aenea, E) Tasa de visita, F) Efectividad de polinización, y G) Tiempo de manipulación. 
plants in the community (Morales \& Traveset 2008). Here, we observed that $L$. corvina carried on average a larger amount of $A$. ligtu pollen and less pollen grains of other plant species inhabiting in RC than in TF, and ZA (Table 1), which could explain in part the highest pollination effectiveness estimation. Contrary, L. aenea in ZA carried more pollen of others plant species than $L$. corvina in $\mathrm{TF}$, but this pollinator still showed a higher effectiveness (Table 3). This difference could be explaining by individual preferences and the different modes that pollinator species have to interact with the flower. Different species could be explaining the differences in the pollinator effectiveness, however, there is another important factor, and that is how the pollinator interact with the flowers (i.e, pollinator behavior). L. corvina and $L$. aenea showed almost the same average handling time $(\mathrm{RC}=3.4 \mathrm{~s} / \mathrm{visit}, \mathrm{ZA}=3.5 \mathrm{~s} / \mathrm{visit})$ and they have higher pollinator effectiveness respect to the main pollinator of TF, which also showed the lowest HT (TF $=2.8$ $\mathrm{s} / \mathrm{visit}$ ). The time that pollinators spend in a flower can be tightly related to the amount of pollen grains that they are able to extract from the flower (Ohashi 2002). Therefore, it is expected that the more time the insect spend on the flower; the more pollen it may extract. Nevertheless, this must be explored more carefully in order to determine if this effectively has the any impact on pollinator effectiveness.

In summary, this work has revealed that the same genus and/or pollinator species can have different effectiveness across A. ligtu populations. In the light of this evidence,

TABle 1. Corolla size of Alstroemeria ligtu, Principal pollinator species, Pollinator's proboscis length, Pollen grains of $A$. ligtu and from other plant species carried by the principal pollinator species in each study population. / Tamaño de la corolla de Alstroemeria ligtu, Polinizador principal, Largo de la proboscis del polinizador, Granos de polen de A. ligtu y de otras especies de plantas acarreados por el polinizador principal en cada población en estudio.

\begin{tabular}{|c|c|c|c|c|c|}
\hline Population & $\begin{array}{l}\text { Corolla AREA } \\
\left(\mathrm{mm}^{2}\right)\end{array}$ & PRINCIPAL POLLINATOR (N) & $\begin{array}{c}\text { ProboscIDE } \\
\text { LENGTH (mm) }\end{array}$ & $\begin{array}{l}\text { PolLEN } A . \text { LIGTU } \\
\quad \text { (grains } / \mathrm{ml} \text { ) }\end{array}$ & $\begin{array}{c}\text { POLLEN FROM } \\
\text { OTHER SPECIES } \\
\text { (grains/ml) }\end{array}$ \\
\hline Rio Clarillo (RC) & $9.1 \pm 2.3$ & Lasia corvina (28) & $1.6 \pm 0.2$ & $158 \pm 139$ & $20 \pm 31$ \\
\hline Termas del Flaco (TF) & $5.8 \pm 1.4$ & Lasia corvina (21) & $1.7 \pm 0.2$ & $75 \pm 111$ & $21 \pm 30$ \\
\hline Zapata (ZA) & $7.1 \pm 2$ & Lasia aenea (12) & $1.2 \pm 0.06$ & $55 \pm 49$ & $39 \pm 63$ \\
\hline
\end{tabular}

TABLE 2. Visitation rate differences of the five most frequent pollinator species in each Alstroemeria ligtu populations after ANOVA analysis. Populations: Río Clarillo (RC), Termas del Flaco (TF) and Cuesta Zapata (ZA). / Diferencias en la tasa de visita de los cinco polinizadores más frecuentes de cada población de Alstroemeria ligtu despúes de un analisis ANDEVA. Poblaciones: Río Clarillo (RC), Termas del Flaco (TF) y Cuesta Zapata (ZA).

\begin{tabular}{lccccc}
\hline Population & DF & SS & MS & F value & \multicolumn{1}{c}{ P } \\
\hline Zapata (ZA) & 1 & 0.13 & 0.13 & 8.45 & 0.0036 \\
Rio Clarillo (RC) & 1 & 3.05 & 3.05 & 115.81 & $2.2 \mathrm{e}-16$ \\
Termas del Flaco (TF) & 1 & 0.21 & 0.21 & 133.88 & $2.2 \mathrm{e}-16$ \\
\hline
\end{tabular}

TABLE 3. Pollination effectiveness (PE), Visitation rate (VR), and Handling time (HT) difference of the most frequent pollinator species of each Alstroemeria ligtu populations after a GLM model with Gaussian distribution. Populations: $\mathrm{RC}=\mathrm{Río} \mathrm{Clarillo}, \mathrm{TF}=\mathrm{Termas}$ del Flaco and ZA= Cuesta Zapata. / Diferencias en efectividad de polinización (PE), Tasa de visita (VR), y Tiempo de manipulación (HT) de la especie de polinizador más frecuente de cada población de Alstroemeria ligtu después de un modelo GLM con distribución gausiana. Poblaciones: $\mathrm{RC}=$ Río Clarillo, $\mathrm{TF}=$ Termas del Flaco y ZA= Cuesta Zapata.

\begin{tabular}{llllll}
\hline & Population & Estimate & Std. error & T Value & \multicolumn{1}{c}{$P$} \\
\hline PE & Zapata (ZA) & -0.32 & 0.076 & -4.25 & $2.31 \mathrm{e}-05$ \\
& Termas del Flaco (TF) & -0.28 & 0.075 & -3.73 & 0.0002 \\
\hline \multirow{2}{*}{ VR } & Zapata (ZA) & 0.0017 & 0.033 & 0.052 & 0.95 \\
& Termas del Flaco (TF) & -0.031 & 0.041 & -0.768 & 0.44 \\
\hline \multirow{2}{*}{ HT } & Zapata (ZA) & -0.06 & 0.018 & -3.72 & 0.0002 \\
& Termas del Flaco (TF) & -0.11 & 0.017 & -6.39 & $2.81 \mathrm{e}-10$ \\
\hline
\end{tabular}


future investigations must focus in determining the pollinator efficiency (Schupp et al. 2017), that is to say, how the quality of pollination performance by a species (e.g., visitation and pollen extraction) could affect the quantity of pollination (i.e., pollen deposition and seed production), and consequently plant population fitness. Under a scenario of spatial variation of pollinator assemblage and effectiveness in $A$. ligtu, it is possible that local conditions can drive local plant adaptation, which could stimulate the generation of a mosaic of phenotypic plant selection across their range of distribution.

\section{ACKNOWLEDGEMENTS}

The authors are grateful to L. Carrasco, M. Zúñiga and M. Agnes for their fieldwork assistance. Also, we thanks to Catalina González-Browne for their important comments made to this manuscript. This study was supported by Fondecyt 11110120 grants awarded to AG. Thanks to Corporación Nacional Forestal (CONAF) for granting permits to work on their estate.

\section{REFERENCES}

Aigner, P.A. 2001. Optimality modeling and fitness tradeoffs: When should plants become pollinator specialists? Oikos 95: 177-184.

Arredondo-NúÑEz, A. 2010. Guía de polen Reserva Nacional Los Ruiles. Alvimpress, Santiago. 69 pp.

Arroyo, M.T.K., Uslar, P. 1993. Breeding systems in a temperate Mediterranean-type climate montane sclerophyllous forest in central Chile. Botanical Journal of the Linnean Society 111(1): 83-102.

Conner, J.K., Rush, S. 1996. Effects of flowers size and number on pollination visitation to wild radish, Raphanus raphanistrum. Oecologia 105: 509-516.

Di Castri, F., Hajek, E.R. 1976. Bioclimatología de Chile. Vicerrectoria Académica. Universidad Católica de Chile, Santiago. 128 pp.

GonzÁlez, A.V., Murúa, M., Ramírez, P.A. 2014. Temporal and spatial variation of the pollinator assemblages in Alstroemeria ligtu (Alstroemeriaceae). Revista Chilena de Historia Natural 87(1): 5.

González, A.V., Murúa, M.M., Pérez, F. 2015. Floral integration and pollinator diversity in the generalized plant-pollinator system of Alstroemeria ligtu (Alstroemeriaceae). Evolutionary Ecology 29(1): 63-75.

Griffin, A., Hingston, A., Ohmart, C. 2009. Pollinators of Eucalyptus regnans (Myrtaceae), the world's tallest flowering plant species. Australian Journal of Botany 57(1): 18-25.

Hegland, S.J., Boeke, L. 2006. Relationships between the density and diversity of floral resources and flower visitor activity in a temperate grassland community. Ecological Entomology 31(5): 532-538.

Herrera, C.M. 2005. Plant generalization on pollinators: species property or local phenomenon? American Journal of Botany 92(1): 13-20.

KAY, K.M., SARgent, R.D. 2009. The role of animal pollination in plant speciation: integrating ecology, geography, and genetics. Annual Review of Ecology, Evolution, and Systematics 40: 637-656.

Morales, C.L., Traveset, A. 2008. Interspecific pollen transfer: magnitude, prevalence and consequences for plant fitness. Critical Reviews in Plant Sciences 27(4): 221-238.

Murúa, M., Espíndola, A. 2015. Pollination syndromes in a specialized plant-pollinator interaction: does floral morphology predict pollinators in Calceolaria? Plant Biology 17(2): 551-557.

Ne’eman, G., Jürgens, A., Newstrom-Lloyd L., Potts S.G., DAFNI A. 2010. A framework for comparing pollinator performance: effectiveness and efficiency. Biological Reviews 85: 435-451.

Oнаsнi, K. 2002. Consequences of floral complexity for bumblebee-mediated geitonogamous self-pollination in Salvia nipponica Miq. (Labiatae). Evolution 56: 24142423.

Ollerton, J., Johnson, S.D., Hingston, A.B. 2006. Geographical variation in diversity and specificity of pollination systems. In: Waser, N., Ollerton, J. (eds.), Plant-pollinator interactions: from specialization to generalization. $283 \mathrm{pp}$.

Rosas-Guerrero, V., Aguilar, R., Martén-Rodríguez, S., Ashworth, L., Lopezaraiza-Mikel, M., Bastida, J.M., QuesadA, M. 2014. A quantitative review of pollination syndromes: do floral traits predict effective pollinators? Ecology Letters 17(3): 388-400.

SAHLI, H.F., Conner, J.K. 2011. Testing for conflicting and nonadditive selection: floral adaptation to multiple pollinators through male and female fitness. Evolution: International Journal of Organic Evolution 65(5): 1457-1473.

Schupp, E.W., Jordano, P., Gómez, J.M. 2017. A general framework for effectiveness concepts in mutualisms. Ecology Letters 20: $577-590$.

STebBins, G.L. 1970. Adaptive radiation of reproductive characteristics in angiosperms, I: pollination mechanisms. Annual Review of Ecology and Systematics 1(1): 307-326.

WASER, N.M. 1983. The adaptive nature of floral traits: ideas and evidence. pp: 241-285. In: Real, L. (ed.), Pollination biology. Academic Press, New York.

Waser, N.M., Chittka, L., Price, M.V., Williams, N.M., Ollerton, J. 1996. Generalization in pollination systems, and why it matters. Ecology 77(4): 1043-1060. 


\section{APPENDIX}

ApPendix 1. Visitation rates of pollination assemblages of each Alstroemeria ligtu var. simsii population. Populations: Río Clarillo (RC), Termas del Flaco (TF) and Cuesta Zapata (ZA). / Tasa de visita del ensamble de polinizadores en cada población de Alstroemeria ligtu var. simsii. Poblaciones: Río Clarillo (RC), Termas del Flaco (TF) y Cuesta Zapata (ZA).

\begin{tabular}{|c|c|c|c|c|c|}
\hline \multirow[b]{2}{*}{ ORDEN } & \multirow[b]{2}{*}{ FAMILY } & \multirow[b]{2}{*}{ PolLinAtor SPECIES } & \multicolumn{3}{|c|}{ VISITATION RATE (visits $*$ flower ${ }^{-1} * h^{-1}$ ) } \\
\hline & & & $\begin{array}{c}\text { Río Clarillo } \\
\text { (RC) }\end{array}$ & $\begin{array}{l}\text { TERMAS DEL } \\
\text { FlaCo (TF) }\end{array}$ & $\begin{array}{c}\text { Cuesta ZaPATA } \\
\text { (ZA) }\end{array}$ \\
\hline Diptera & Bombyliidae & Anthrax sp. & $0.024 \pm 0.015$ & - & - \\
\hline Diptera & Bombyliidae & Bombyliidae & - & $0.002 \pm 0.001$ & - \\
\hline Diptera & Bombyliidae & Bombyliidae & $0.032 \pm 0.013$ & - & $0.015 \pm 0.008$ \\
\hline Diptera & Acroceridae & Lasia aenea & - & - & $0.496 \pm 0.089$ \\
\hline Diptera & Acroceridae & Lasia corvina & $0.957 \pm 0.136$ & $0.145 \pm 0.016$ & $0.015 \pm 0.008$ \\
\hline Diptera & Tabanidae & Tabanidae & - & $0.015 \pm 0.003$ & - \\
\hline Diptera & Tabanidae & Tabanidae & $0.006 \pm 0.004$ & - & - \\
\hline Diptera & Tabanidae & Dasybasis sp. & - & - & $0.029 \pm 0.021$ \\
\hline Hymenoptera & Apidae & Alloscirtetica gayi & $0.035 \pm 0.018$ & $0.0001 \pm 0.0001$ & $0.005 \pm 0.003$ \\
\hline Hymenoptera & Halictidae & Caenohalictus azarae & $0.017 \pm 0.010$ & $0.003 \pm 0.001$ & $0.039 \pm 0.018$ \\
\hline Hymenoptera & Apidae & Centris nigerrima & - & - & $0.105 \pm 0.031$ \\
\hline Hymenoptera & Halictidae & Halictidae & $0.015 \pm 0.009$ & - & - \\
\hline Hymenoptera & Halictidae & Lasioglossum & - & $0.0001 \pm 0.0001$ & - \\
\hline Hymenoptera & Apidae & Manuelia gayi & $0.262 \pm 0.064$ & - & $0.040 \pm 0.017$ \\
\hline Hymenoptera & Megachilidae & Megachile cinerea & - & $0.0005 \pm 0.0003$ & $0.009 \pm 0.005$ \\
\hline Hymenoptera & Megachilidae & Notanthidium steloides & $0.053 \pm 0.019$ & - & $0.022 \pm 0.009$ \\
\hline Hymenoptera & Pieridae & Phoebis sp. & $0.003 \pm 0.003$ & - & $0.111 \pm 0.028$ \\
\hline Hymenoptera & Halictidae & Ruizantheda mutabilis & $0.011 \pm 0.007$ & - & - \\
\hline Hymenoptera & Apidae & Svastrides melanura & $0.120 \pm 0.060$ & $0.004 \pm 0.001$ & $0.012 \pm 0.007$ \\
\hline Hymenoptera & Vespidae & Vespula germanica & $0.002 \pm 0.002$ & $0.0001 \pm 0.0001$ & $0.026 \pm 0.008$ \\
\hline Lepidoptera & Nymphalidae & Nymphalidae sp. & $0.007 \pm 0.004$ & - & $0.052 \pm 0.016$ \\
\hline Lepidoptera & Pieridae & Tatochila sp. & - & - & $0.013 \pm 0.008$ \\
\hline
\end{tabular}

Recibido: 01.10.2018

Aceptado: 25.01.2019 